Article

\title{
Recycled Wastewater and Reverse Osmosis Brine Use for Halophytes Irrigation: Differences in Physiological, Nutritional and Hormonal Responses of Crithmum maritimum and Atriplex halimus Plants
}

\author{
María José Gómez-Bellot ${ }^{1}$, Beatriz Lorente ${ }^{1}$, María Fernanda Ortuño ${ }^{1, *} \mathbb{D}^{\mathbb{D}}$, Sonia Medina ${ }^{2} \mathbb{D}$, \\ Ángel Gil-Izquierdo ${ }^{2}$ (), Sebastián Bañón ${ }^{3}{ }^{-1}$ and María Jesús Sánchez-Blanco ${ }^{1}$
}

check for updates

Citation: Gómez-Bellot, M.J.; Lorente, B.; Ortuño, M.F.; Medina, S.; Gil-Izquierdo, Á.; Bañón, S.; Sánchez-Blanco, M.J. Recycled Wastewater and Reverse Osmosis Brine Use for Halophytes Irrigation: Differences in Physiological,

Nutritional and Hormonal Responses of Crithmum maritimum and Atriplex halimus Plants. Agronomy 2021, 11, 627. https://doi.org/10.3390/ agronomy11040627

Academic Editor: Jose Beltrao

Received: 8 February 2021

Accepted: 22 March 2021

Published: 26 March 2021

Publisher's Note: MDPI stays neutral with regard to jurisdictional claims in published maps and institutional affiliations.

Copyright: (c) 2021 by the authors. Licensee MDPI, Basel, Switzerland. This article is an open access article distributed under the terms and conditions of the Creative Commons Attribution (CC BY) license (https:// creativecommons.org/licenses/by/ $4.0 /)$.
1 Department of Irrigation, Centro de Edafología y Biología Aplicada del Segura (CEBAS-CSIC), P.O. Box 164, 30100 Espinardo-Murcia, Spain; mjgb@cebas.csic.es (M.J.G.-B.); blorente@cebas.csic.es (B.L.); quechu@cebas.csic.es (M.J.S.-B.)

2 Research Group of Quality, Safety and Bioactivity of Plant Foods, Food Science and Technology Department, Centro de Edafología y Biología Aplicada del Segura (CEBAS-CSIC), P.O. Box 164, 30100 Espinardo-Murcia, Spain; smescuderdo@cebas.csic.es (S.M.); angelgil@cebas.csic.es (Á.G.-I.)

3 Department of Agricultural Engineering, UPCT-Technical University of Cartagena, 30203 Cartagena, Spain; Sebastian.Arias@upct.es

* Correspondence: mfortuno@cebas.csic.es; Tel.: +34-968-396-200

\begin{abstract}
Halophytes are capable of coping with excessive $\mathrm{NaCl}$ in their tissues, although some species may differ in their degree of salt tolerance. In addition, it is not clear whether they can tolerate other confounding factors and impurities associated with non-conventional waters. The experiment was performed in a greenhouse with Crithmum maritimum and Atriplex halimus plants, growing on soil and irrigated with two different water types: reclaimed wastewater (RWW) (EC: $0.8-1.2 \mathrm{dS} \mathrm{m}^{-1}$ ) and reverse osmosis brine (ROB) (EC: 4.7-7.9 dS m ${ }^{-1}$ ). Both species showed different physiological and nutritional responses, when they were irrigated with ROB. Atriplex plants reduced leaf water potential and maintained leaf turgor as consequence of an osmotic adjustment process. Atriplex showed higher intrinsic water use efficiency than Crithmum, regardless of the type of water used. In Crithmum, the water status and photosynthetic efficiency were similar in both treatments. Crithmum presented a higher leaf accumulation of $\mathrm{B}$ and $\mathrm{Ca}$ ions, while Atriplex a higher amount of $\mathrm{K}, \mathrm{Mg}$, $\mathrm{Na}$ and $\mathrm{Zn}$. Crithmum plants irrigated with ROB presented higher concentrations of 1-aminocyclopropane-1carboxylic acid and trans-zeatin-glucoside, whereas abscisic acid concentration was lower. Atriplex showed a lower concentration of trans-zeatin-riboside and scopoletin. The characteristics associated to water irrigation did not influence negatively the development of any of these species, which confirms the use of brine as an alternative to irrigate them with conventional waters.
\end{abstract}

Keywords: salinity; non-conventional irrigation; water status; photosynthetic efficiency; plant nutrition; phytohormones; growth

\section{Introduction}

The Mediterranean region is characterized by a climate with prolonged drought periods where isolated and torrential rains are frequent. In addition, soils usually present some extent of salinization, as well as a poor structure and a scarce vegetation cover, which increases water erosion [1]. Aridity might increase in this area due to climate change [2]. In this sense, water scarcity is becoming more frequent due to the overexploitation of aquifers as a result of an increasing demand [3]. This prevents the recovery of these sources of supply during recharge periods and it leads to the depletion of water resources. Agriculture is the largest user of water supplies, consuming over $70 \%$ of the abstracted freshwater globally [4]. In recent years, wastewater reclamation, recycling and reuse has gained attention in many 
countries, to ensure water security and to develop effective strategies for sustainable utilization of water resources in agricultural and landscape irrigation [5-8]. This kind of water is recovered from domestic, municipal, and industrial wastewater treatment plants and it may have specific treatments depending of its purpose [9]. Its use implies benefits of different nature, such as the pressure alleviation on other water resources [10] and the reduction of fertilizer cost due to its high nutrient content [11], producing high-value crops and crop commodities [12]. However, depending on its source and type of treatment, there is a wide range of chemical contaminants persisting in reclaimed wastewater, such as inorganic compounds, heavy metals, pathogens and many other complex compounds [13], that may affect negatively crop yield or be unsafe to human consumption [14,15]. In the case of plants with gardening and reforestation purposes, in addition to the problems related to the high salt concentrations and heavy metals which may affect growth, stabilization and quality of plants [16], the presence of persistent organic pollutants such as organochlorine pesticides can pose threats to ecosystems due to their biological accumulation through the trophic chain.

Some of these mentioned water treatments include membrane processes such as reverse osmosis $(\mathrm{RO})$, whose main application is water desalination. Desalination technologies, particularly the reverse osmosis process, have been increasingly adopted to produce freshwater from alternative sources [17]. The water residue or RO brine resulting from this process is usually removed without using it, due to its high quantity of salts, causing environmental problems and high economic costs [18]. This has led some authors to consider that the reuse of agricultural and industrial brines for crop production can be beneficial in preventing discharge of brines into natural environmental [19]. Either way, there is a need to consider this water as a new non-potable water source [20] and to improve brine management strategies [21]. Numerous projects have been developed for the utilization of saline water on conventional crops and forages [22-24]. However, the low salinity tolerance of most crops limits the amount of saline water that can be applied for conventional crop production. In this sense, the selection and adoption of suitable plant species and genotypes are key factors to improve agricultural and green areas quality, as well as to decrease management costs. Halophytes plants are the native flora of saline soils, which survive completing their whole life cycle in such environments [25]. Halophytes are not only used in landscaping or as ornamental plants, they are also used to treat saline effluence, or cultivated with industrial purposes. Last but not least, they are being used for forage/fodder, human food and even gourmet vegetables [26]. The viability of plants in saline habitats depends on their ability to cope with several major constraints as (i) water deficit, (ii) restriction of $\mathrm{CO}_{2}$ uptake, (iii) ion toxicity and (iv) nutrient imbalance [27]. Therefore, halophytic species may differ in their degree of salt tolerance [28]. To achieve this tolerance and be able to deal with salt stress, a wide range of morphological, physiological and biochemical mechanisms take place on the whole plant, at tissue and at cellular/molecular levels [29,30].

The main salt tolerance target is keeping the ionic excess away from the metabolic active tissues to preserve leaf photosynthesis and meristematic activity [31]. This aim is obtained generally thanks to processes such as accumulation of osmotic adjustment substances, ion-selective absorption and compartmentalization, morphological changes in root and leaf tissues, antioxidant and hormone regulation [32-34]. Taking into account this last process, phytohormones emerge as cellular signal molecules with key functions in the regulation of plant responses to abiotic stresses. Recently, a considerable amount of evidence has shown that phytohormones are signals connecting root and shoot, triggering responses to external stress [35]. To avoid water losses due to evapotranspiration, plants regulate cell biophysics promoting cellular turgor decrease and leaf stomatal closure. Consequently, a reduction of stomatal conductance limits $\mathrm{CO}_{2}$ uptake and photosynthesis ultimately [36]. The reduction in photosystem II efficiency by excess salinity is associated with decreasing total chlorophyll content. In salt tolerant plants, PSII photochemistry is reported to be more resilient to salt stress than $\mathrm{CO}_{2}$ fixation processes, with a balance 
between the light-harvesting processes and effective energy dissipating mechanisms [37,38]. Nevertheless, while halophytes are clearly capable of coping with excessive amounts of $\mathrm{NaCl}$ in their tissues $[39,40]$, it is not clear whether they can tolerate other confounding factors and impurities associated with wastewater irrigation.

Crithmum maritimum (Apiaceae), or sea fennel, is a food halophyte found on rocky shores of Mediterranean Sea and Atlantic Ocean [41]. Several uses of $C$. maritimum are known for culinary purposes and its leaves have been used for aromatic and medicinal purposes as a tonic and diuretic [42]. C. maritimum is moderately tolerant to $\mathrm{NaCl}$, known as a facultative halophyte, since it does not require salt for maximal growth. On the other hand, Atriplex halimus, or Mediterranean saltbush, is a xerohalophytic perennial shrub native to the Mediterranean. It is considered desirable due to its high fodder quality [43] and due to its potential for use in ecological restoration programs [44]. A. halimus is well adapted to salinity by tolerating salts internally and/or by its excretition [45] through its trichomes [46].

Based on the above considerations, in this study we evaluate if the irrigation with reclaimed wastewater and brine from a reverse-osmosis water treatment of two halophytes species (Crithmum maritimum and Atriplex halimus) growing on soil, is suitable for revegetation purposes. The objectives of the study were (i) to test the use of saline effluent such as brine from a reverse osmosis (RO) desalination treatment to irrigate Crithmum maritimum and Atriplex halimus, (ii) to study the growth of two halophyte forage species to factors associated with wastewater and (iii) to compare physiological traits, nutritional and hormonal status of two halophytes. Comparative data relating plant physiological and agronomic processes may prove beneficial information on the tolerance of plants to abiotic stresses.

\section{Materials and Methods}

\subsection{Plant Material and Experiment Conditions}

The experiment was performed in a greenhouse located in the municipal wastewater treatment plant (WWTP) of Balsicas (Murcia, Spain) (latitude $37^{\circ} 47^{\prime} 48^{\prime \prime} \mathrm{N}$, longitude $0^{\circ} 57^{\prime} 36^{\prime \prime} \mathrm{W}$ ), from April 2018 to January 2019. Two halophyte species typical from Mediterranean areas, Crithmum maritimum (CM) and Atriplex halimus (AH) were grown. Seedlings of both species $(n=72)$ were transplanted on 24 April 2018 into the greenhouse, which has a silty clay loam soil. The average bulk density was $1.46 \mathrm{~g} \mathrm{~cm}^{-3}$ and the volumetric soil water content at field capacity and permanent wilting point were $36.3 \%$ and $19.8 \%$, respectively. The experimental plot consisted of 6 rows, with a total length of approximately 6 meters and 12 plants per row, following a planting pattern of $0.5 \times 1 \mathrm{~m}^{2}$. The microclimatic conditions showed that during the experimental period, the average values of the air temperature, relative humidity and radiation were around $21^{\circ} \mathrm{C}, 63 \%$ and $500 \mathrm{Wm}^{-2}$, respectively. Irrigation and agronomic management were established by the farmer. Plants were irrigated by a drip irrigation system with one lateral pipe per plant row and one emitter $\left(3 \mathrm{~L} \mathrm{~h}^{-1}\right)$. The volume of water applied depended on the season, the climatic conditions and the plant development. Irrigation was applied to bring soil moisture to the field capacity (up to a depth of $30 \mathrm{~cm}$ as the depth of root expansion). Soil moisture was measured using capacitive probes (ECHO-5, Decagon Devices Inc., Pullman, WA, USA) connected to a datalogger (CR1000, Campbell Scientific Inc., Logan, UT, USA). Irrigation was scheduled twice a week, activating it until soil moisture reached field capacity.

\subsection{Irrigation Water Treatments and Experimental Design}

Before starting with the different irrigation treatments, plants were irrigated with water from the Irrigation Community of Campo de Cartagena $\left(<0.9 \mathrm{dS} \mathrm{m}^{-1}\right)$. Irrigation treatments began on 23 May 2018, four weeks after transplanting. During the thirty-five following weeks, two irrigation treatments were applied at 100\% field capacity: (1) Reclaimed wastewater (RWW) as control (EC: $0.8-1.2 \mathrm{dS} \mathrm{m}^{-1}$ ), obtained by feeding wastewater to several tertiary treatments in the WWTP, such as ultrafiltration, granular activated carbon 
filter and four reverse osmosis membrane elements, and (2) reverse osmosis brine (ROB) (EC: $4.7-7.9 \mathrm{dS} \mathrm{m}^{-1}$ ) which was a water residue result of the above mentioned process. The salinity level in the brine was medium, avoiding excessive salinization and soil degradation. Water quality of both treatments was similar during the experiment, it just varied in a narrow range, depending on the characteristics of the input wastewater treated at the WWTP (Table 1). In this sense, and in general terms, the concentration of the reverse osmosis brine components was much higher than those found in reclaimed wastewater. The concentration of $\mathrm{Na}, \mathrm{Cl}$ and $\mathrm{SO}_{4}$ was around six times higher in brine than in reclaimed wastewater, while the concentrations of anions such as $\mathrm{F}, \mathrm{NO}_{3}$ and $\mathrm{PO}_{4}$ was around three times higher in brine than in reclaimed wastewater. Elements such as $\mathrm{B}, \mathrm{Ni}, \mathrm{Cu}$ and $\mathrm{Zn}$ showed a similar concentration in both waters (Table 1).

Table 1. Physicochemical analyses of the irrigation treatments. Data is presented as average values of the water samples collected during the experiment.

\begin{tabular}{ccc}
\hline & RWW & ROB \\
\hline EC (dS m $\left.{ }^{-1}\right)$ & 0.994 & 5.403 \\
$\left.\mathrm{pH}^{-1}\right)$ & 7.199 & 7.124 \\
$\mathrm{SS}\left(\mathrm{mg} \mathrm{L}^{-1}\right)$ & 1.276 & 4.269 \\
Turbidity (NTU) & 0.570 & 0.686 \\
E. coli (UFC 100 mL $\left.{ }^{-1}\right)$ & 0.00 & 0.00 \\
$\mathrm{Fe}(\mathrm{ppm})$ & 0.04 & 0.07 \\
$\mathrm{~K}(\mathrm{ppm})$ & 17.54 & 98.14 \\
$\mathrm{Mg}(\mathrm{ppm})$ & 8.45 & 56.12 \\
$\mathrm{Mn}(\mathrm{ppm})$ & 0.05 & 0.27 \\
$\mathrm{Na}(\mathrm{ppm})$ & 160.16 & 1003.29 \\
$\mathrm{Cl}(\mathrm{ppm})$ & 210.01 & 1208.92 \\
$\mathrm{P}(\mathrm{ppm})$ & 2.68 & 10.04 \\
$\mathrm{~S}(\mathrm{ppm})$ & 1.88 & 9.11 \\
$\mathrm{~B}(\mathrm{ppm})$ & 0.821 & 0.877 \\
$\mathrm{Ni}(\mathrm{ppm})$ & 0.008 & 0.008 \\
$\mathrm{Cu}(\mathrm{ppm})$ & 0.009 & 0.009 \\
$\mathrm{Zn}(\mathrm{ppm})$ & 0.054 & 0.044 \\
$\mathrm{~F}(\mathrm{ppm})$ & 0.07 & 0.24 \\
$\mathrm{NO}_{2}(\mathrm{ppm})$ & 0.10 & 0.10 \\
$\mathrm{NO}_{3}(\mathrm{ppm})$ & 5.64 & 15.70 \\
$\mathrm{PO}(\mathrm{ppm})$ & 8.21 & 30.72 \\
$\mathrm{SO}_{4}(\mathrm{ppm})$ & 129.6 & 877.58 \\
\hline
\end{tabular}

EC, electrical conductivity; SS, suspended solids; E. coli, Escherichia coli bacteria.

The treatments followed a randomized design, with three replications per treatment (6 plants per replication, 18 plants per treatment and species). Three rows were irrigated with RWW from the tertiary effluent and the other three with ROB in the plot.

\subsection{Plant Water Relations}

Leaf water relations were measured throughout the experiment in nine plants per treatment (three plants per replication). Leaf water potential $\left(\Psi_{\text {leaf }}\right)$ was measured at midday, collecting a mature leaf according to Scholander et al. [47] using a pressure chamber (Model 3000; Soil Moisture Equipment Co., Santa Barbara, CA, USA). Leaves were placed in the chamber within $20 \mathrm{~s}$ of collection and pressurized at a rate of $0.02 \mathrm{MPa} \mathrm{s}^{-1}$ [48]. Adjacent leaves were also collected, frozen immediately in liquid nitrogen $\left(-196{ }^{\circ} \mathrm{C}\right)$ and subsequently stored at $-30{ }^{\circ} \mathrm{C}$. After thawing, the leaf osmotic potential ( $\left.\Psi_{\text {os }}\right)$ was measured in the extracted sap using a WESCOR 5520 vapor pressure osmometer (Wescor Inc., Logan, UT, USA), according to Gucci et al. [49]. The leaf osmotic potential at full turgor $\left(\Psi_{100 s}\right)$ was estimated as indicated above for $\Psi_{\text {os }}$, after placed in distilled water overnight to reach full saturation. The leaf turgor potential $\left(\Psi_{t}\right)$ was estimated as the difference between leaf water potential ( $\left.\Psi_{\text {leaf }}\right)$ and leaf osmotic potential $\left(\Psi_{\text {os }}\right)$. 


\subsection{Gas Exchange and Chlorophyll Fluorescence Parameters}

Leaf gas exchange and chlorophyll fluorescence were measured simultaneously at midday throughout the experiment using a gas exchange system (LI-6400; LI-COR Inc., Lincoln, NE, USA), fitted with an infrared gas analyzer attached to a leaf chamber fluorometer (LCF) (6400-40B, $2 \mathrm{~cm}^{2}$ leaf area, Licor Bioscience, Inc., Lincoln, NE, USA). The reference $\mathrm{CO}_{2}$, photosynthetically active radiation (PAR) and speed of the circulating air flow inside the system were set at $400 \mathrm{ppm}$, at $2000 \mu \mathrm{mol} \mathrm{m}^{-2} \mathrm{~s}^{-1}$ and at $500 \mu \mathrm{mol} \mathrm{s}{ }^{-1}$, respectively. The leaf photosynthetic rate $\left(\mathrm{P}_{\mathrm{n}}\right)$, stomatal conductance $\left(\mathrm{g}_{\mathrm{s}}\right)$, internal $\mathrm{CO}_{2}$ concentration $\left(\mathrm{C}_{\mathrm{i}}\right)$, the excitation capture efficiency of open centers $\left(\mathrm{F}_{\mathrm{v}}{ }^{\prime} / \mathrm{F}_{\mathrm{m}}{ }^{\prime}\right)$, the effective quantum efficiency of photosystem II (Phi PSII), photochemical quenching coefficient (qP) and the electron transport rate (ETR) were measured [50]. The intrinsic water use efficiency $\left(W U E_{i}\right)$ was determined as the $P_{n} / g_{s}$ ratio, and the photosynthetic efficiency was expressed as the relationship between the degree of stomatal opening necessary to reach a certain level of photosynthesis.

\subsection{Qualitative and Quantitative Analysis of Phytohormones and Chlorophyll Content in Leaves}

Analytical standards of the phytohormones 1-aminocyclopropane-1-carboxylic acid, giberellic-5 acid, trans-Zeatin glucoside, abscisic acid, salicylic acid and scopoletin were purchased from Santa Cruz Biotechnologies (Dallas, TX, USA). trans-Zeatin, trans-Zeatin riboside and [2H5]-trans-Zeatin were obtained from Olchemlm (Olomouc, Czech Republic). Ethanol, Water LC-MS quality, dimethyl sulfoxide, formic acid and methanol were bought from Panreac (Barcelona, Spain). Acetonitrile was from J.T. Baker (Thermo Fisher Scientific Inc., Waltham, MA, USA).

For the identification and quantification of hormones, $0.1 \mathrm{~g}$ of fresh leaves from 6 samples per treatment were crushed in a mortar with liquid nitrogen and stored at $-80^{\circ} \mathrm{C}$. Then, they were vortexed with $0.5 \mathrm{~mL} 80 \%$ methanol/water $(v / v)$ and incubated at $4{ }^{\circ} \mathrm{C}$ during $30 \mathrm{~min}$ and finally centrifuged at $15,000 \mathrm{rpm}(20,627 \times \mathrm{g})$, at $4{ }^{\circ} \mathrm{C}$ for $15 \mathrm{~min}$. The supernatant was kept in ice and then it was further extracted with $0.5 \mathrm{~mL} 80 \%$ methanol/water $(v / v)$ after being incubated and centrifuged under the same conditions described above. Finally, both supernatants from the two previous extractions were passed through Chromafix $\mathrm{C}_{18}$ solid phase extraction cartridge (Macherey Nagel, Düren, Germany) (previously activated with $3 \mathrm{~mL} 80 \%$ methanol/water $(v / v)$. The eluted sample was concentrated to dryness by the use of a rotary vacuum evaporator during approximately $3 \mathrm{~h}$ (Speedvac, Thermo, Waltham, MA, USA). Then, the dry residue was resuspended with $200 \mu \mathrm{L}$ de $20 \%$ metanol/water $(v / v)$, sonicated for $8 \mathrm{~min}$ and filtrated through $0.45 \mu \mathrm{m}$ polyethersulfone filter (Millipore) and finally injected in a ultra-high-performance liquid chromatography (UHPLC) coupled triple quadrupole mass spectrometry (UHPLC-ESI-QqQ-MS/MS) for qualitative and quantitative analysis [51].

Chromatographic separation of phytohormones and the phytoalexin scopoletine was performed by a method previously described by Albacete et al., 2008 with slight modifications. Briefly, we used a UHPLC coupled to a 6460 UHPLC-ESI-QqQ-MS/MS (Agilent Technologies, Waldbronn, Germany), using a $\mathrm{BEH} \mathrm{C}_{18}$ analytical column $(2.1 \times$ $100 \mathrm{~mm}, 1.7 \mu \mathrm{m}$ ) (Waters, Milford, MA, USA). Mobile phases A $\left(\mathrm{H}_{2} \mathrm{O}\right)$ contained $0.01 \%$ formic acid $(\mathrm{v} / \mathrm{v})$ and $\mathrm{B}$ acetonitrile. The flow rate was $0.2 \mathrm{~mL} / \mathrm{min}$ using a linear gradient scheme: (t; \%B): $(0.0 ; 19.00),(2.5 ; 90.00),(4.5 ; 90.00),(6.00 ; 19.00),(8.00 ; 19.00)$. The injection volume was $10 \mu \mathrm{L}$. The column temperatures were $40^{\circ} \mathrm{C}$. The operating conditions for the ionization source were as follows: Gas flow: $8 \mathrm{~L} / \mathrm{min}$, Nebulizer: 45 psi, Capillary Voltage: $4000 \mathrm{~V}$ (positive mode) and $2750 \mathrm{~V}$ (negative mode), Nozzle Voltage: $1000 \mathrm{~V}$ (positive mode) and $1500 \mathrm{~V}$ (negative mode), Gas Temperature: $300{ }^{\circ} \mathrm{C}$, Sheath Gas Temperature: $375^{\circ} \mathrm{C}$ and Jetstream Gas Flow: $11 \mathrm{~L} / \mathrm{min}$. The ion optics and fragmentation conditions are detailed in Table 2. Data acquisition and processing were performed using Mass Hunter software version B.08.00 (Agilent Technologies). The quantification of the phytohormones and scopoletin detected in the samples was performed according to standard curves freshly prepared each day of analysis. 
Table 2. Ultra-high-performance liquid chromatography (UHPLC) coupled triple quadrupole mass spectrometry (UHPLC-QqQ-MS/MS) parameters for the identification, identity confirmation (second MRM transition) and quantification of the phytohormones.

\begin{tabular}{|c|c|c|c|c|c|c|}
\hline Hormone $^{\mathrm{Z}}$ & $\begin{array}{l}\text { Retention } \\
\text { Time (min) }\end{array}$ & $\begin{array}{c}\text { Ionization } \\
\text { Mode }\end{array}$ & $\begin{array}{c}\text { Parent } \\
\text { Ion }(\mathrm{m} / \mathrm{z})\end{array}$ & $\begin{array}{l}\text { Ion Fragments } \\
(\mathrm{m} / \mathrm{z})\end{array}$ & $\begin{array}{c}\text { Fragmentor } \\
\text { (V) }\end{array}$ & $\begin{array}{l}\text { Collision } \\
\text { Energy (V) }\end{array}$ \\
\hline \multirow[t]{2}{*}{ ACC } & \multirow[t]{2}{*}{1.312} & \multirow[t]{2}{*}{ Positive } & \multirow[t]{2}{*}{102.1} & $56.0^{Y}$ & 80 & 15 \\
\hline & & & & $28.0^{x}$ & 80 & 15 \\
\hline \multirow[t]{2}{*}{$\mathrm{tZ}$} & \multirow[t]{2}{*}{1.724} & \multirow[t]{2}{*}{ Positive } & \multirow[t]{2}{*}{220.2} & 202.0 & 80 & 15 \\
\hline & & & & 136.0 & 80 & 15 \\
\hline tZdeuter & 1.744 & Positive & 225.2 & 136.3 & 80 & 15 \\
\hline \multirow[t]{2}{*}{ tZ-GLC } & \multirow[t]{2}{*}{1.742} & \multirow[t]{2}{*}{ Positive } & \multirow[t]{2}{*}{382.4} & 220.0 & 80 & 15 \\
\hline & & & & 202.0 & 80 & 15 \\
\hline \multirow[t]{2}{*}{ tZ-Rib } & \multirow[t]{2}{*}{1.743} & \multirow[t]{2}{*}{ Positive } & \multirow[t]{2}{*}{352.4} & 219.7 & 80 & 15 \\
\hline & & & & 136.0 & 80 & 15 \\
\hline \multirow[t]{2}{*}{ SC } & \multirow[t]{2}{*}{2.802} & \multirow[t]{2}{*}{ Positive } & \multirow[t]{2}{*}{193.2} & 132.5 & 80 & 20 \\
\hline & & & & 149.1 & 80 & 20 \\
\hline \multirow[t]{2}{*}{ GA5 } & \multirow[t]{2}{*}{3.095} & \multirow[t]{2}{*}{ Negative } & \multirow[t]{2}{*}{329.4} & 145.0 & 80 & 39 \\
\hline & & & & 285.0 & 80 & 18 \\
\hline \multirow[t]{2}{*}{$\mathrm{ABA}$} & \multirow[t]{2}{*}{3.130} & \multirow[t]{2}{*}{ Negative } & \multirow[t]{2}{*}{263.3} & 152.9 & 80 & 14 \\
\hline & & & & 204.1 & 80 & 18 \\
\hline \multirow[t]{2}{*}{ SA } & \multirow[t]{2}{*}{3.219} & \multirow[t]{2}{*}{ Negative } & \multirow[t]{2}{*}{137.1} & 93.2 & 80 & 15 \\
\hline & & & & 65.4 & 80 & 15 \\
\hline
\end{tabular}

Z ABA, abscisic acid; ACC, 1-aminocyclopropane-1-carboxylic acid; GA5, giberellic-5 acid; SA, salicylic acid; SC, scopoletin; $\mathrm{tZ}$, trans-zeatin; Tz-Glc, trans-zeatin glucoside; Tz-Rib, trans-zeatin riboside. ${ }^{\mathrm{Y}} \mathrm{MRM}$ transition for quantification. ${ }^{X}$ MRM transition for confirmation.

At the end of the experiment, the chlorophyll content was assayed according to Inskeep and Bloom [52] in the leaves of four plants per treatment. The extraction was made from $50 \mathrm{mg}$ of fresh material in $5 \mathrm{~mL}$ of $80 \%$ acetone in the dark at $4{ }^{\circ} \mathrm{C}$. The extract was read at $647 \mathrm{~nm}$ for chlorophyll-a, and $664 \mathrm{~nm}$ for chlorophyll-b in an Uvikon 940 spectrophotometer (Kontron Instruments AG, Zürich, Switzerland).

\subsection{Determination of Mineral Content in Leaves and Plant Canopy}

The inorganic mineral content of dry leaves was determined at the end of the experiment in three plants per treatment (one sample per replication) by means of emission spectrophotometry. The leaves were oven dried at $80{ }^{\circ} \mathrm{C}$, ground, and sieved through a 2-mm nylon mesh before analysis. A chemical analysis of water irrigation treatments was performed. The nutrient concentrations were determined in an extract digested with $\mathrm{HNO}_{3}: \mathrm{HClO}_{4}(2: 1, v / v)$ using an inductively coupled plasma optical emission spectrometer (ICP-OES IRIS INTREPID II XDL). At the end of the experiment, the plant canopy was determined in both species by measuring height and width from the top, selecting nine representative plants per treatment (three plants per replication).

\subsection{Statistics}

In the experiment, all plants $(n=72)$ were randomly assigned to each treatment, with three replications for each treatment. The data were analyzed by one-way ANOVA and two-way ANOVA using IBM SPSS Statistics 25 . The independent variables were irrigation water and species. Treatment means were separated with Duncan's multiple range test $(p \leq 0.05)$.

\section{Results}

\subsection{Plant Water Relations}

Throughout the experiment, the highest values of leaf water potential and osmotic water potential were found in Crithmum plants, with no differences in the osmotic water potential by the type of water. The lowest values of these parameters were found in Atriplex plants, especially in those irrigated with ROB (Figure 1A,B). Atriplex plants showed also the lowest values of osmotic potential at full turgor during the experiment (Figure 1C). In general, leaf turgor potential was higher in Atriplex plants than in Crithmum, while there were differences only by the irrigation type at the beginning of the experiment, ROB treatment showing higher values than RWW treatment (Figure 1D). 


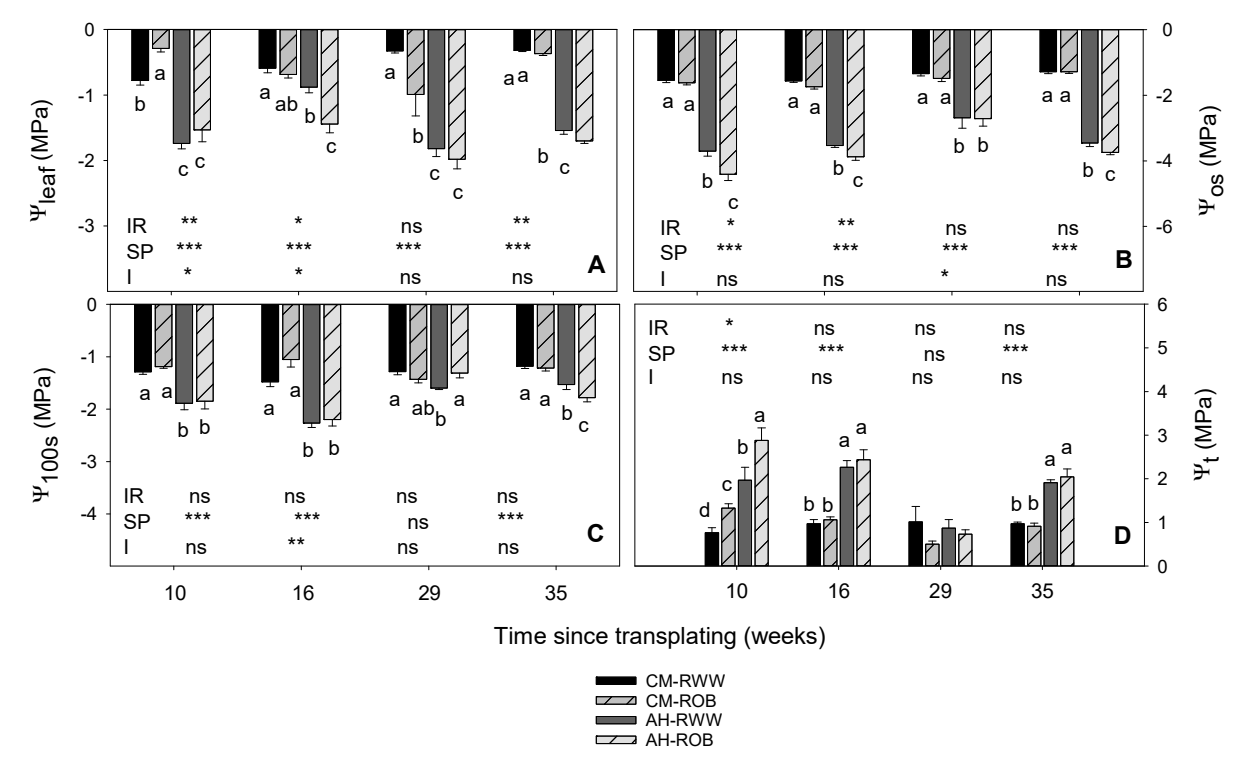

Figure 1. Leaf water potential ( $\left.\Psi_{\text {leaf }}\right)\left(\right.$ A), osmotic water potential $\left(\Psi_{\mathrm{oS}}\right)(\mathbf{B})$, osmotic water potential at full turgor $\left(\Psi_{100 \mathrm{~s}}\right)(\mathrm{C})$ and leaf turgor potential $\left(\Psi_{\mathrm{t}}\right)(\mathrm{D})$ in Crithmum maritimum $(\mathrm{CM})$ and Atriplex halimus (AH), irrigated with reclaimed wastewater (RWW) and reverse osmosis brine (ROB). Results were from one way and two-way ANOVA tests in these parameters, for independent variables (irrigation, IR, and species, SP) and their interaction (I). Different lowercase letters indicate significant differences between treatments according to Duncan's test at $p \leq 0.05$. ${ }^{*} p<0.05,{ }^{* *} p<0.01$ and *** $p<0.001 . p>0.05$ non-significant differences are indicated by "ns".

\subsection{Gas Exchange and Chlorophyll Fluorescence Parameters}

In both species, the irrigation with ROB induced a decrease in $\mathrm{g}_{\mathrm{s}}$ compared with the RWW treatment during the first half of the experiment, showing Atriplex irrigated with ROB the lowest values (Table 3). In fact, regardless the type of irrigation, the lowest gs values were found in Atriplex. Nevertheless, there were no differences in $P_{n}$ by irrigation type, except at the beginning of the experiment (week 10), when irrigation with ROB decreased $P_{n}$ in both species, being this decrease only significant for Atriplex plants (Table 3). Regardless the type of water used, Atriplex showed the highest values of $P_{n}$ at week 12 and 16, while Crithmum showed the highest ones at the end of the experiment. The intrinsic water use efficiency (WUEi) barely experienced variations resulting from the type of irrigation water. Despite these unclear variations, in general terms, Atriplex plants showed a higher WUEi than Crithmum (Table 3).

The intercellular $\mathrm{CO}_{2}\left(\mathrm{C}_{\mathrm{i}}\right)$ in both species was hardly affected by the type of water used during the experiment (Figure 2A).

Regardless the irrigation type, Crithmum showed higher $\mathrm{C}_{\mathrm{i}}$ values than Atriplex. No statistical differences in $\mathrm{F}_{\mathrm{v}^{\prime}} / \mathrm{F}_{\mathrm{m}^{\prime}}$ were observed by the type of water used during the experiment, while irrespective of the irrigation type, Crithmum showed the highest values throughout almost the whole experiment (Figure 2B). Regardless the type of water used, Atriplex showed increased PhiPSII, qP and ETR values most of the weeks (Figure 2C-E). The photosynthetic efficiency showed a similar trend line for both irrigation treatments in Crithmum, since for the same photosynthesis value, the stomatal conductance was similar, although from $12 \mu \mathrm{mol} \mathrm{m}{ }^{-2} \mathrm{~s}^{-1}$ of $\mathrm{P}_{\mathrm{n}}$ approximately, plants irrigated with ROB showed a $g_{s}$ slightly higher (Figure 3A). In Atriplex, plants irrigated with ROB had a lower photosynthetic efficiency than those irrigated with the RWW, since from $13 \mu \mathrm{mol} \mathrm{m}{ }^{-2} \mathrm{~s}^{-1}$ of $P_{n}$ approximately, for the same $P_{n}$ value, the stomatal conductance of plants irrigated with ROB was higher (Figure 3B). 
Table 3. Stomatal conductance $\left(g_{s}\right)$, net photosynthetic rate $\left(P_{n}\right)$, and intrinsic water use efficiency $\left(\mathrm{WUE}_{\mathrm{i}}\right)$ in Crithmum maritimum (CM) and Atriplex halimus $(\mathrm{AH})$, irrigated with reclaimed wastewater (RWW) and reverse osmosis brine (ROB). Results were from one-way and two-way ANOVA tests on these parameters for independent variables (Irrigation, IR, and species, SP) and their interaction (I). Values are means of nine samples.

\begin{tabular}{|c|c|c|c|c|c|}
\hline \multicolumn{6}{|c|}{ 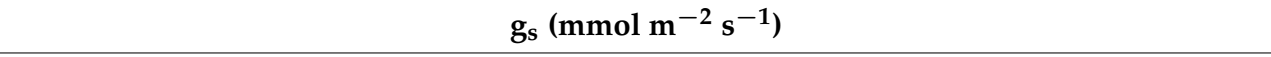 } \\
\hline Week & 10 & 12 & 14 & 16 & 19 \\
\hline CM-RWW & $268.4 \mathrm{a}$ & $210.9 \mathrm{a}$ & $199.2 \mathrm{~b}$ & 110.5 & $333.3 \mathrm{a}$ \\
\hline CM-ROB & $211.9 \mathrm{ab}$ & $177.3 \mathrm{ab}$ & $299.1 \mathrm{a}$ & 122.8 & $285.4 \mathrm{ab}$ \\
\hline AH-RWW & $152.8 \mathrm{bc}$ & $123.6 \mathrm{bc}$ & $120.4 \mathrm{bc}$ & 94.1 & $204.4 \mathrm{~b}$ \\
\hline AH-ROB & $105.0 \mathrm{c}$ & $58.4 \mathrm{c}$ & $95.5 c$ & 92.4 & $196.7 \mathrm{~b}$ \\
\hline Sig. & $* *$ & $* *$ & $* * *$ & ns & * \\
\hline IR & * & $*$ & $\mathrm{~ns}$ & ns & ns \\
\hline $\mathrm{SP}$ & $* *$ & $* *$ & $* * *$ & ns & $* *$ \\
\hline $\mathrm{I}$ & ns & ns & $*$ & ns & ns \\
\hline \multicolumn{6}{|c|}{$P_{n}\left(\mu \mathrm{mol} \mathrm{m}{ }^{-2} s^{-1}\right)$} \\
\hline Week & 10 & 12 & 14 & 16 & 19 \\
\hline CM-RWW & $16.93 \mathrm{a}$ & $10.47 \mathrm{~b}$ & 10.76 & $6.587 \mathrm{~b}$ & $26.69 \mathrm{a}$ \\
\hline CM-ROB & $12.90 \mathrm{ab}$ & $9.56 \mathrm{~b}$ & 14.10 & $7.104 \mathrm{~b}$ & $24.18 \mathrm{ab}$ \\
\hline AH-RWW & $18.82 \mathrm{a}$ & $16.89 \mathrm{a}$ & 14.52 & $14.68 \mathrm{a}$ & $18.21 \mathrm{~b}$ \\
\hline AH-ROB & $10.17 \mathrm{~b}$ & $15.60 \mathrm{a}$ & 11.64 & $14.42 \mathrm{a}$ & $17.57 \mathrm{~b}$ \\
\hline Sig. & * & $* *$ & ns & $* * *$ & * \\
\hline IR & $* * *$ & ns & ns & ns & ns \\
\hline SP & ns & $* * *$ & ns & $* * *$ & $* *$ \\
\hline $\mathrm{I}$ & $*$ & ns & ns & ns & ns \\
\hline \multicolumn{6}{|c|}{ WUEi $\left(P_{n} / g_{s}\right)$} \\
\hline Week & 10 & 12 & 14 & 16 & 19 \\
\hline CM-RWW & $69.0 \mathrm{~b}$ & $51.4 \mathrm{~b}$ & $54.8 \mathrm{~b}$ & $62.2 \mathrm{~b}$ & 80.9 \\
\hline CM-ROB & $65.3 \mathrm{~b}$ & $105.8 \mathrm{~b}$ & $50.2 \mathrm{~b}$ & $60.2 \mathrm{~b}$ & 87.6 \\
\hline AH-RWW & $119.1 \mathrm{a}$ & $157.1 \mathrm{~b}$ & $113.6 \mathrm{a}$ & $157.6 \mathrm{a}$ & 92.2 \\
\hline AH-ROB & $91.0 \mathrm{~b}$ & $369.6 \mathrm{a}$ & $120.0 \mathrm{a}$ & 155.9 a & 93.5 \\
\hline Sig. & $* * *$ & $* *$ & $* * *$ & $* * *$ & ns \\
\hline IR & $*$ & $*$ & ns & ns & ns \\
\hline SP & $* * *$ & $* *$ & $* * *$ & $* * *$ & ns \\
\hline I & $*$ & ns & ns & ns & ns \\
\hline
\end{tabular}

Different lowercase letters indicate significant differences between treatments according to Duncan's test at $p \leq 0.05 .{ }^{*} p<0.05,{ }^{* *} p<0.01$ and ${ }^{* * *} p<0.001 . p>0.05$ non-significant differences are indicated by "ns". 


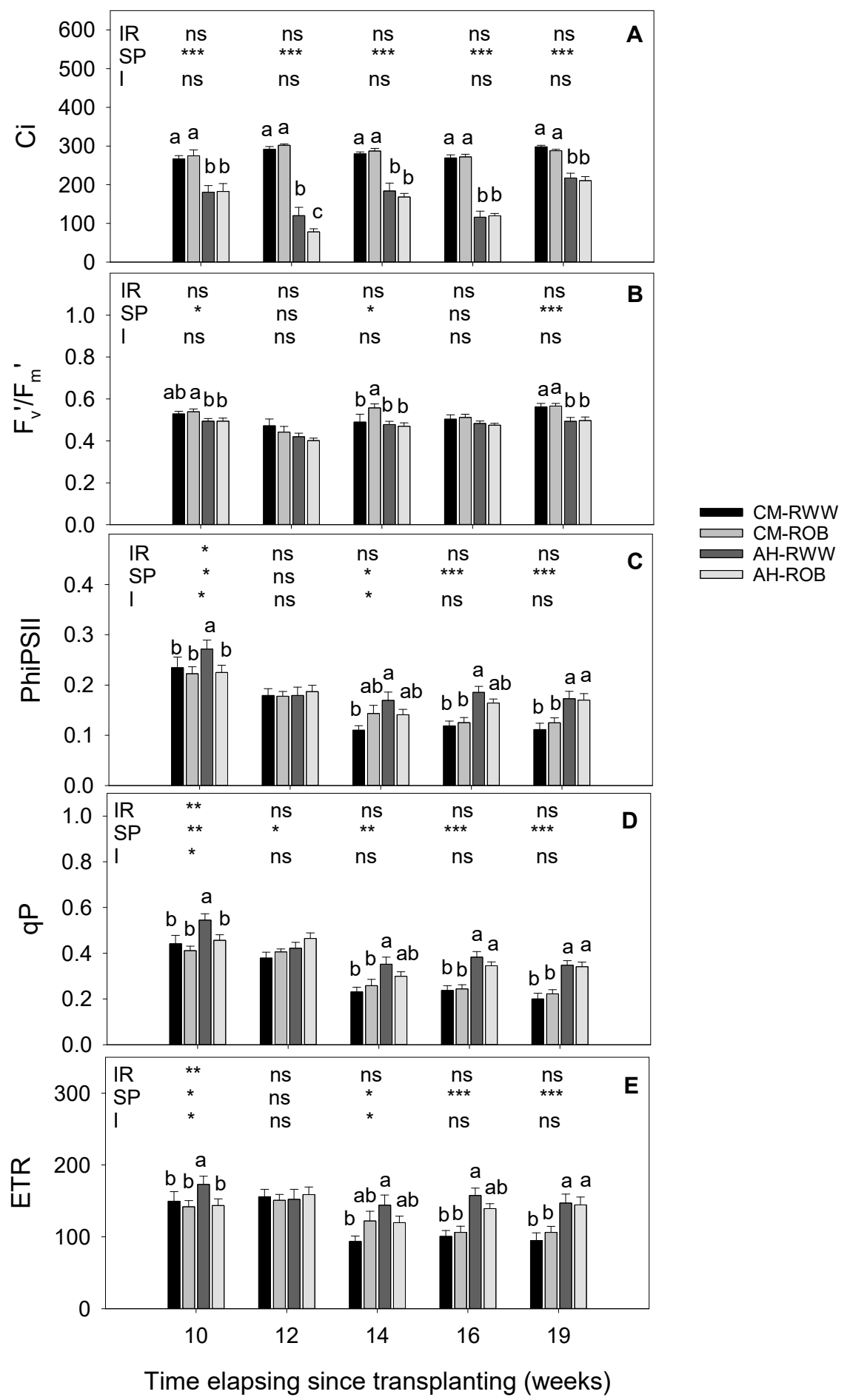

Figure 2. Internal $\mathrm{CO}_{2}$ concentration $\left(\mathrm{C}_{\mathrm{i}}\right)(\mathrm{A})$; The excitation capture efficiency of open centers $\left(\mathrm{F}_{\mathrm{v}}{ }^{\prime} / \mathrm{F}_{\mathrm{m}}{ }^{\prime}\right)$ (B); PSII effective quantum yield (PhiPSII) (C); Photochemical quenching coefficient (qP) (D); and the apparent electron transport rate (ETR) (E) in Crithmum maritimum (CM) and Atriplex halimus (AH) irrigated with reclaimed wastewater (RWW) and reverse osmosis brine (ROB). Results were from one way and two-way ANOVA tests in these parameters, for independent variables (irrigation, IR, and species, SP) and their interaction (I). Different lowercase letters indicate significant differences between treatments according to Duncan's test at $p \leq 0.05$. ${ }^{*} p<0.05,{ }^{* *} p<0.01$ and *** $p<0.001 . p>0.05$ non-significant differences are indicated by "ns". 


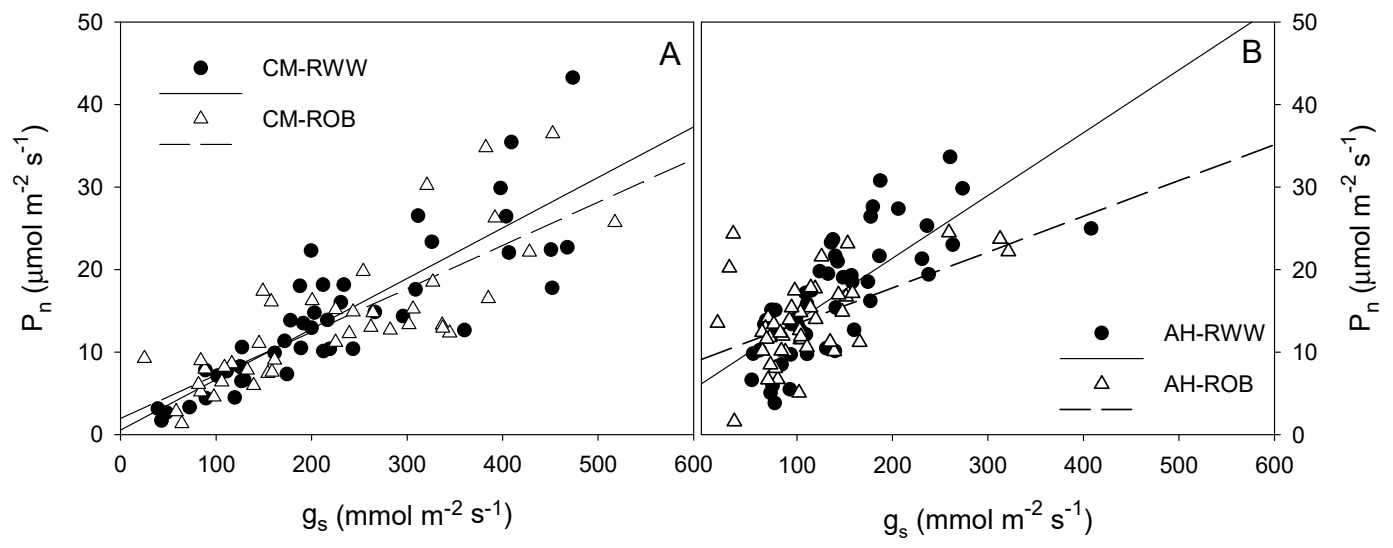

Figure 3. Photosynthetic efficiency as the relationship between photosynthesis and stomatal conductance in Crithmum maritimum (CM) (A) and Atriplex halimus (AH) (B) irrigated with reclaimed wastewater (RWW) and reverse osmosis brine (ROB).

\subsection{Phytohormones and Chlorophyll Content in Leaves}

The leaf chlorophyll content was not affected by the type of water although the highest values were found in Atriplex (Table 4).

Table 4. Leaf chlorophyll content (Chl A, Chl B and Chl T) in Crithmum maritimum (CM) and Atriplex halimus (AH), irrigated with reclaimed wastewater (RWW) and reverse osmosis brine (ROB). Results were from one-way and two-way ANOVA tests on these parameters for independent variables (Irrigation, IR, and species, SP) and their interaction (I). Values are means of four samples.

\begin{tabular}{cccc}
\hline & \multicolumn{2}{c}{ Leaf Mineral Content $\left(\mathbf{m g ~ g}^{-\mathbf{1}}\right)$} & Chl T \\
\hline & Chl A & Chl B & $0.710 \mathrm{~b}$ \\
CM-RWW & $0.539 \mathrm{~b}$ & $0.171 \mathrm{~b}$ & $0.961 \mathrm{~b}$ \\
CM-ROB & $0.719 \mathrm{~b}$ & $0.242 \mathrm{~b}$ & $2.597 \mathrm{a}$ \\
AH-RWW & $2.048 \mathrm{a}$ & $0.549 \mathrm{a}$ & $2.663 \mathrm{a}$ \\
AH-ROB & $2.107 \mathrm{a}$ & $0.556 \mathrm{a}$ & $* * *$ \\
Sig. & $* * *$ & ** & ns \\
IR & ns & ns & ns \\
\hline SP & $* *$ & ns & ns
\end{tabular}

Different lowercase letters indicate significant differences between treatments according to Duncan's test at $p \leq 0.05$. ${ }^{*} p<0.05,{ }^{* *} p<0.01$ and ${ }^{* * *} p<0.001 . p>0.05$ non-significant differences are indicated by " $\mathrm{ns}$ ".

Several phytohormones were identified in leaves in both species: the precursor of Ethylene, 1-Aminocyclopropane-1-carboxylic acid (ACC), cytokinins (TZ, TZ-rib and TZ-glc), gibberellins (GA5), abscisic acid (ABA), salicylic acid (SA) and the phytoalexin scopoletin (SC).

Some of them (ACC, TZ-rib and TZ-glc) were modified by the type of irrigation water. However, they were affected differently depending on the species. A higher ACC and TZglc concentration and lower ABA concentration were observed in Crithmum plants irrigated with ROB compared with those irrigated with water from RWW (Figure 4). Atriplex plants irrigated with ROB showed lower concentration of TZ-rib and SC compared with those irrigated with water from RWW (Figure 4). Regarding only species, higher values of ACC, TZ-glc and SA were found in Crithmum than in Atriplex plants, while higher values of TZ, GA5, ABA and the phytoalexin SC were found in Atriplex than in Crithmum (Figure 4). 


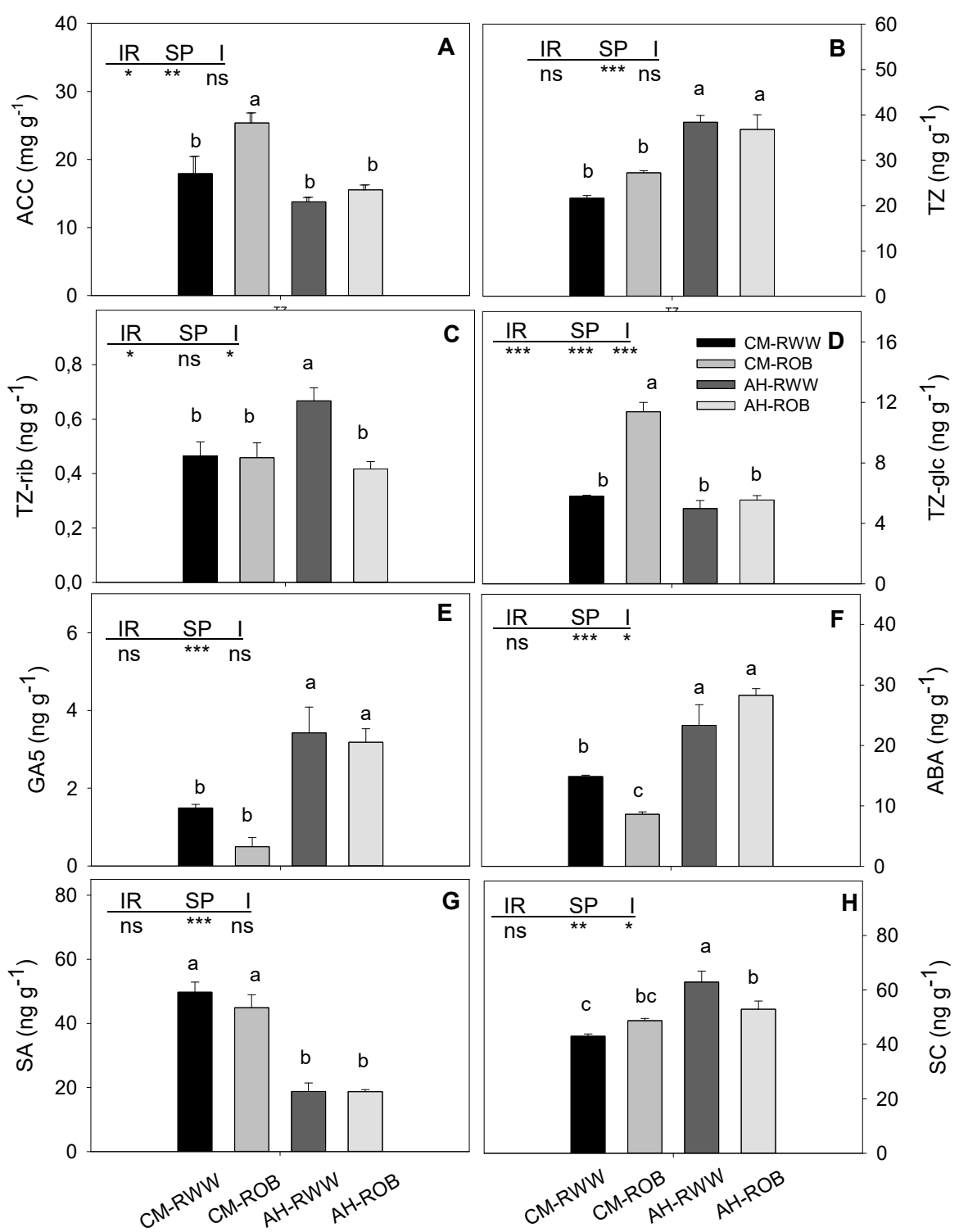

Figure 4. 1-Aminocyclopropane-1-carboxylic acid (ACC) (A), cytokinins (TZ) (B), (TZ-rib) (C), (TZglc) (D), gibberellins (GA5) (E), abscisic acid (ABA) (F), salicylic acid (SA) (G) and scopoletin (SC) (H), in Crithmum maritimum (CM) and Atriplex halimus (AH) irrigated with reclaimed wastewater (RWW) and reverse osmosis brine (ROB). Results were from one way and two-way ANOVA tests in these parameters, for independent variables (irrigation, IR, and species, SP) and their interaction (I). Different lowercase letters indicate significant differences between treatments according to Duncan's test at $p \leq 0.05$. ${ }^{*} p<0.05,{ }^{* *} p<0.01$ and ${ }^{* *} p<0.001 . p>0.05$ non-significant differences are indicated by "ns".

\subsection{Leaf Mineral Concentration and Plant Canopy Development}

Regardless the species, the concentrations of $\mathrm{B}, \mathrm{Ca}, \mathrm{Fe}, \mathrm{K}, \mathrm{Mg}, \mathrm{Na}, \mathrm{P}$ and $\mathrm{Zn}$ ions in leaves did not show any significant changes by the type of water used (Table 5). Only B concentration in Crithmum leaves was lower after irrigating with ROB. Regardless the type of water, a higher amount of $\mathrm{B}$ and $\mathrm{Ca}$ ions accumulated in Crithmum leaves than in Atriplex, and a higher amount of $\mathrm{K}, \mathrm{Mg}, \mathrm{Na}$ and $\mathrm{Zn}$ accumulated in Atriplex leaves than in Crithmum (Table 5). 
Table 5. Leaf mineral concentration in Crithmum maritimum (CM) and Atriplex halimus (AH), irrigated with reclaimed wastewater (RWW) and reverse osmosis brine (ROB). Results were from one-way and two-way ANOVA tests on these parameters for independent variables (irrigation, IR, and species, SP) and their interaction (I). Values are means of three samples.

\begin{tabular}{|c|c|c|c|c|c|c|c|c|}
\hline ppm & B & $\mathrm{Ca}$ & $\mathrm{Fe}$ & $\mathbf{K}$ & Mg & $\mathrm{Na}$ & $\mathbf{P}$ & $\mathrm{Zn}$ \\
\hline CM-RWW & $329.0 \mathrm{a}$ & $45,143.3 \mathrm{a}$ & 126.5 & $34,673.3 b$ & $3497.0 \mathrm{~b}$ & $24,931.7 b$ & 3313.2 & $31.1 \mathrm{~b}$ \\
\hline CM-ROB & $263.5 b$ & $44,260.0 \mathrm{a}$ & 112.9 & $19,582.8 b$ & $3343.0 \mathrm{~b}$ & $17,809.2 \mathrm{~b}$ & 3324.8 & $40.4 \mathrm{ab}$ \\
\hline AH-RWW & $248.9 \mathrm{~b}$ & $11,013.3 \mathrm{~b}$ & 92.6 & $76,266.7 \mathrm{a}$ & $9628.3 \mathrm{a}$ & $56,661.7 \mathrm{a}$ & 3218.5 & $52.2 \mathrm{a}$ \\
\hline AH-ROB & $248.0 \mathrm{~b}$ & 9726.7 b & 94.5 & $65,616.7 \mathrm{a}$ & $9315.0 \mathrm{a}$ & $71816.7 \mathrm{a}$ & 2879.2 & $50.1 \mathrm{a}$ \\
\hline Sig. & & $*$ & ns & $* *$ & $* * *$ & $* *$ & ns & ns \\
\hline IR & $\mathrm{ns}$ & $\mathrm{ns}$ & ns & ns & ns & ns & ns & ns \\
\hline SP & $*$ & $* *$ & ns & $* * *$ & $* * *$ & $* * *$ & ns & $*$ \\
\hline $\mathrm{I}$ & $\mathrm{ns}$ & ns & ns & ns & ns & ns & ns & ns \\
\hline
\end{tabular}

Different lowercase letters indicate significant differences between treatments according to Duncan's test at $p \leq 0.05$. * $p<0.05,{ }^{* *} p<0.01$ and ${ }^{* * *} p<0.001 . p>0.05$ non-significant differences are indicated by "ns".

At the end of the experiment, the structure of the plant or its canopy was not statistically affected by the type of water used (Table 6). Atriplex showed a slight reduction of the canopy caused by the irrigation with brine but with no significant differences, while Crithmum reached numerically greater canopy by the irrigation with ROB, but not statistically. Regardless the type of water used, Atriplex plants developed a greater canopy than Crithmum (Table 6).

Table 6. Plant canopy determined by measuring height and width of plants in Crithmum maritimum (CM) and Atriplex halimus (AH), irrigated with reclaimed wastewater (RWW) and reverse osmosis brine (ROB). Results were from one-way and two-way ANOVA tests on these parameters for independent variables (irrigation, IR, and species, SP) and their interaction (I). Values are means of three samples.

\begin{tabular}{cccc}
\hline & \multicolumn{3}{c}{ CANOPY (cm) } \\
\cline { 2 - 4 } & Height $\mathbf{( H )}$ & Width $\mathbf{( W )}$ & $\mathbf{H} \times \mathbf{W}$ \\
\hline CM-RWW & $24.44 \mathrm{~b}$ & $28.94 \mathrm{~b}$ & $770.50 \mathrm{c}$ \\
CM-ROB & $28.72 \mathrm{~b}$ & $33.94 \mathrm{~b}$ & $1008.17 \mathrm{c}$ \\
AH-RWW & $65.94 \mathrm{a}$ & $104.56 \mathrm{a}$ & $6880.00 \mathrm{a}$ \\
AH-ROB & $57.72 \mathrm{a}$ & $97.72 \mathrm{a}$ & $5723.67 \mathrm{ab}$ \\
& $* * * * * *$ & $\mathrm{~ns}$ \\
IR & $\mathrm{ns}$ & $\mathrm{ns}$ & $* * *$ \\
SP & ns** & ns & $\mathrm{ns}$ \\
I & $\mathrm{ns}$ & $\mathrm{ns}$ & \\
\hline
\end{tabular}

Different lowercase letters indicate significant differences between treatments according to Duncan's test at $p \leq 0.05 .{ }^{* *} p<0.001 . p>0.05$ non-significant differences are indicated by "ns".

\section{Discussion}

Crithmum maritimum and Atriplex halimus are naturally salt-tolerant plants, being great candidates to replace conventional edible sensitive plants in marginal and degraded lands [53]. Atriplex may even be useful for phytoremediation of former mining areas [54]. Although the salinity range in our experiment was moderately low, the use of reclaimed wastewater and brine has scarcely been proved in these plants. It is not clear whether they can tolerate other confounding factors and impurities associated with wastewater [55]. Regarding water relations, both species performed differently to the use of saline effluent from reverse osmosis ( $\mathrm{RO}$ ) brine. The reduction of leaf water potential by the irrigation of ROB was more evident in Atriplex plants, which reduced the osmotic leaf potential to maintain leaf turgor values similar to those plants irrigated with water from RWW. When water potential is suddenly reduced, osmotic adjustment occurs rapidly to allow partial turgor recovery and re-establishment of water potential gradient for water uptake, and the loosening ability of the cell wall increases [56]. Many plants accumulate organic osmolytes in their cytoplasm [57] to increase cellular water retention without affecting 
normal metabolic processes. However, Crithmum plants did not need to reduce the osmotic potential. ROB water seemed to decrease gas exchange, especially $\mathrm{g}_{\mathrm{s}}$, in both plant species respect to the water from RWW during the first half of experiment, Atriplex in a greater extent. However, leaf chlorophyll content was not affected by the type of irrigation water, most halophyte plants are able to stabilize chloroplasts and thylakoids to protect photosynthesis mechanisms [58]. Little literature has been found about the role of the photosynthetic activity in these species $[59,60]$. Benzarti et al. [60] observed that $\mathrm{g}_{\mathrm{s}}$ in Atriplex portulacoides was only reduced above $200 \mathrm{Mm}\left(\approx 18 \mathrm{dS} \mathrm{m}^{-1}\right) \mathrm{NaCl}$ in the water. Although there were hardly any changes in the fluorescence parameters and WUEi by the type of water in these plants, the photosynthetic efficiency results indicated that Atriplex plants irrigated with RO brine needed to open more their stomas than those irrigated with RWW, to reach the same level of $\mathrm{P}_{\mathrm{n}}$. As a consequence, Atriplex plants had a greater loss of water and higher energy costs than Crithmum [61]. The greater concentration of mineral ions in brine water than in water from RWW, such as $\mathrm{K}, \mathrm{Mg}$, Na, $\mathrm{S}$ and $\mathrm{P}$, did not lead to a higher leaf ion accumulation in both species. Nevertheless, each plant species had a different preference to accumulate ions in their leaves. Crithmum accumulated higher B and Ca content, the latter transported to the leaves by the transpiration process [62], suggesting a better flow of water to leaves, while Atriplex accumulated higher $\mathrm{K}, \mathrm{Mg}$, $\mathrm{Na}$ and $\mathrm{Zn}$ content. This indicated that each plant species had different mechanisms of ion uptake. In addition, both irrigation waters presented levels of heavy metals within the recommended concentration limits, although levels of salts such as $\mathrm{Na}, \mathrm{Cl}$ and $\mathrm{SO}_{4}$ were considered toxic for most crops [63-65].

Phytohormones have also important roles in salt stress tolerance [66,67]. The biosynthesis of ethylene is induced by many stresses, however, its role is controversial regarding salt stress [68]. Khan et al. [69] reported that increased ethylene biosynthesis in wheat was related to salt tolerance, while other authors claimed that its production might play a negative role in tomato growth, coinciding with an oxidative stress and leaf senescence [70,71]. In our experiment, the increase of ACC in Crithmum plants irrigated with ROB was not related to a negative response of plant physiology, since there was no evidence of oxidative stress or reduction of plant growth. A significant accumulation of ABA is essential to active plant protective mechanisms [72], which regulate leaf water potential and stomatal closing to avoid water losses [73]. It is well known that the increase of ABA synthesis and the decrease of TZ production is an effective defense mechanism of plants in response to salt stress [74]. However, in our experiment this behavior was not so clear in Crithmum plants, since $\mathrm{RO}$ brine did not induce the accumulation of ABA. Atriplex performed differently to Crithmum, since a lower leaf accumulation of TZ-rib and SC was observed in plants irrigated with brine compared to those irrigated with water from RWW. Scopoletin (phytoalexin) is a coumarin compound with antifungal properties and inhibitory effects on abiotic stresses [75]. Its accumulation has been correlated with resistance to stresses, such as dehydration and salt toxicity $[75,76]$. This fact might explain that the plants did not suffer salt stress or that salinity was not high enough to cause the accumulation of SC. Some studies showed that Crithmum maritimum is able to maintain growth at high salinity levels, even up to $340 \mathrm{mM} \mathrm{NaCl}[77,78]$. However, Ben Hamed et al. [79] found that DW biomass of Crithmum begun to reduce even at $50\left(4.5 \mathrm{dS} \mathrm{m}^{-1}\right) \mathrm{mM} \mathrm{NaCl}$. In our case, the growth of both species was not affected by the different irrigation treatments, despite that the brine was $5.4 \mathrm{dS} \mathrm{m}^{-1}$ on average. In the Atriplex plants, irrigation with brine slightly reduced the canopy, surely due to lower photosynthetic efficiency showed in these plants. The physiological adaptations to salinity were more evident in Atriplex than in Crithmum plants to maintain growth, when they were irrigated with RO brine. Nedjimi and Daoud [80] and Boughalleb and Denden [81] showed an optimal plant growth in Atriplex at $50 \mathrm{mM}$ $\mathrm{Na}_{2} \mathrm{SO}_{4}$, and at $100 \mathrm{mM} \mathrm{NaCl}$, respectively, declining with a further increase in salinity.

\section{Conclusions}

In general, both species had a different physiological and nutritional response when they were irrigating with ROB. In the case of Atriplex, plants performed adaptations such 
as osmotic adjustment and stomatal regulation to maintain growth in comparison with Crithmum. In Crithmum plants irrigated with ROB, water status and photosynthetic activity performance, including photosynthetic efficiency, were similar to those irrigated with RWW. Nevertheless, the particular characteristics associated to this kind of waters did not seem to influence negatively the development of both species during the stabilization period. Therefore, reclaimed wastewater from tertiary effluence and reverse osmosis brine, such as the wastewater used in this experiment, could be an alternative to irrigation with conventional waters in both species for revegetation or soil preservation purposes.

Author Contributions: Conceptualization, M.J.S.-B.; data curation, M.J.G.-B.; formal analysis, M.J.G.B.; funding acquisition, M.J.S.-B.; investigation, B.L., S.M., Á.G.-I. and S.B.; methodology, B.L., M.F.O., S.M., Á.G.-I., S.B. and M.J.S.-B.; project administration, M.F.O. and M.J.S.-B.; resources, M.J.S.-B. and M.F.O.; supervision, M.F.O.; visualization, M.J.G.-B.; writing-original draft, M.J.G.-B.; writing-review and editing, M.J.G.-B. All authors have read and agreed to the published version of the manuscript.

Funding: This research was supported by Seneca Foundation of Murcia (19903/GERM/15) and by the project RITECAROR-RTI2018-093997-B-100 (MCIU/AEI/FEDER, UE).

Institutional Review Board Statement: Not applicable.

Informed Consent Statement: Not applicable.

Data Availability Statement: Data sharing not applicable.

Conflicts of Interest: The authors declare no conflict of interest. The funders had no role in the design of the study; in the collection, analyses, or interpretation of data; in the writing of the manuscript, or in the decision to publish the results.

\section{References}

1. Benet, A.S.; Castilla, Y.C. Mejora de suelos salinos y control de la erosión en zonas áridas. In Libro de Ponencias y Comunicaciones, XXXII Congreso de la Asociación Española de Parques y Jardines Públicos, Almería, Spain; Asociación Española de Parques y Jardines Públicos: Madrid, Spain, 2005; p. 61.

2. Dai, A. Increasing drought under global warming in observations and models. Nat. Clim. Chang. 2013, 3, 52-58. [CrossRef]

3. Dogan, E.D.; Yasar, A.; Sen, U.; Aydiner, C. Water recovery from treated urban wastewater by ultrafiltration and reverse osmosis for landscape irrigation. Urban Water J. 2016, 13, 553-568. [CrossRef]

4. Singh, A. Poor quality water utilization for agricultural production: An environmental perspective. Land Use Policy 2015, 43, 259-262. [CrossRef]

5. Mizyed, N.R. Challenges to treated wastewater reuse in arid and semi-arid areas. Environ. Sci. Policy 2013, 25, 186-195. [CrossRef]

6. Pedrero, F.; Kalavrouziotis, I.; Alarcón, J.J.; Koukoulakis, P.; Asano, T. Use of treated municipal wastewater in irrigated agriculture-Review of some practices in Spain and Greece. Agric. Water Manag. 2010, 97, 1233-1241. [CrossRef]

7. Bozdoğan, E. Possible use of treated wastewater as irrigation water at urban green area. Turk. J. Agric. Food Sci. Technol. 2015, 3, 35-39. [CrossRef]

8. Saleem, M.; Jabbar, U. Feasibility studies of using domestic wastewater for landscape irrigation purposes near a nuclear power plant. Int. J. Environ. Eng. 2018, 9, 115-129. [CrossRef]

9. EPA: Guidelines for Water Reuse; US Agency for International Development: Washington, DC, USA, 2012.

10. Eslamian, S.; Okhravi, D.; Reyhani, M.N. Urban Water Reuse: Future Policies and Outlooks. In Urban Water Reuse Handbook; Eslamian, S., Ed.; CRC Press: Boca Raton, FL, USA, 2015; pp. 1097-1104.

11. Vivaldi, G.A.; Camposeo, S.; Mastro, M.A.; Lacolla, L.; Lonigro, A.; Rubino, P. Effect of irrigation with different municipal wastewaters on ripening indexes and chemical components of nectarine fruits. Acta Hortic. 2015, 1084, 401-407. [CrossRef]

12. Silber, A.; Israeli, Y.; Elingold, I.; Levi, M.; Levkovitch, I.; Russo, D.; Assouline, S. Irrigation with desalinated water: A step toward increasing water saving and crop yields. Water Resour. Res. 2015, 51, 450-464. [CrossRef]

13. Fatta-Kassinos, D.; Kalavrouziotis, I.K.; Koukoulakis, P.H.; Vasquez, M.I. The risks associated with wastewater reuse and xenobiotics in the agroecological environment. Sci. Total Environ. 2011, 409, 3555-3563. [CrossRef] [PubMed]

14. Mara, D.; Sleigh, A. Estimation of norovirus infection risks to consumers of wastewater-irrigated food crops eaten raw. J. Water Health 2010, 8, 39-43. [CrossRef]

15. Intriago, J.C.; López-Gálvez, F.; Allende, A.; Vivaldi, G.A.; Camposeo, S.; Nicolás, E.N.; Salcedo, F.P. Agricultural reuse of municipal wastewater through an integral water reclamation management. J. Environ. Manag. 2018, 213, 135-141. [CrossRef]

16. Gómez-Bellot, M.J.; Ortuño, M.F.; Nortes, P.A.; Vicente-Sánchez, J.; Fernández, F.; Bañón, S.; Sánchez-Blanco, M.J. Protective effects of Glomus iranicum var. tenuihypharum on soil and Viburnum tinus plants irrigated with treated wastewater under field conditions. Mycorrhiza 2015, 25, 399-409. [CrossRef] 
17. Afrasiabi, N.; Shahbazali, E. RO brine treatment and disposal methods. Desalin. Water Treat. 2011, 35, 39-53. [CrossRef]

18. Darre, N.C.; Toor, G.S. Desalination of water: A review. Curr. Pollut. Rep. 2018, 4, 104-111. [CrossRef]

19. Hamilton, S.J. Review of selenium toxicity in the aquatic food chain. Sci. Total 2004, 326, 1-31. [CrossRef] [PubMed]

20. Nazer, A.; Guzmán, A.; Bolados, L.; González, L.; Pavez, O. Uso de agua de rechazo de plantas depuradoras en la fabricación de hormigones. Obras Proy. 2018, 24, 21-27. [CrossRef]

21. Jones, E.; Qadir, M.; van Vliet, M.T.; Smakhtin, V.; Kang, S.M. The state of desalination and brine production: A global outlook. Sci. Total Environ. 2019, 657, 1343-1356. [CrossRef]

22. Ayars, J.E.; Soppe, R.W.O. Integrated Water Management for Saline Drainage Water Disposal. In Proceedings of the Engineering Salinity Solutions, 1st National Salinity Engineering Conference, Perth, Australia, 1 January 2004; Engineers Australia: Perth, Australia, 2004; p. 9.

23. Miyamoto, S. Appraising Salinity Hazard to Landscape Plants and Soils Irrigated with Moderately Saline Water. 2006. Available online: http:/ / opensiuc.lib.siu.edu/ucowrconfs_2006/102 (accessed on 18 July 2006).

24. Romero-Trigueros, C.; Alarcón-Cabañero, J.J.; Tortosa, P.A.; Gambín, J.M.; Maestre-Valero, J.F.; Nicolás, E.N. Medium-long term effects of saline reclaimed water and regulated deficit irrigation on fruit quality of citrus. J. Sci. Food Agric. 2020, 100, 1350-1357. [CrossRef]

25. Ksouri, R.; Falleh, H.; Megdiche, W.; Trabelsi, N.; Mhamdi, B.; Chaieb, K.; Abdelly, C. Antioxidant and antimicrobial activities of the edible medicinal halophyte Tamarix gallica L. and related polyphenolic constituents. Food Chem. Toxicol. 2019, 47, $2083-2091$. [CrossRef]

26. Flowers, T.J.; Colmer, T.D. Plant salt tolerance: Adaptations in halophytes. Ann. Bot. 2015, 115, 327-331. [CrossRef] [PubMed]

27. Riadh, K.; Wided, M.; Hans-Werner, K.; Chedly, A. Responses of halophytes to environmental stresses with special emphasis to salinity. Adv. Bot. Res. 2010, 53, 117-145.

28. Flowers, T.J.; Munns, R.; Colmer, T.D. Sodium chloride toxicity and the cellular basis of salt tolerance in halophytes. Ann. Bot. 2015, 115, 419-431. [CrossRef]

29. Ashraf, M.P.J.C.; Harris, P.J.C. Potential biochemical indicators of salinity tolerance in plants. Plant Sci. 2004, 166, 3-16. [CrossRef]

30. Koyro, H.W.; Geissler, N.; Hussin, S. Survival at extreme locations: Life strategies of halophytes. In Salinity and Water Stress; Ashraf, M., Ozturk, M., Athar, H.R., Eds.; Springer: Berlin, Germany, 2009; Volume 17, pp. 167-177.

31. Moles, T.M.; Pompeiano, A.; Reyes, T.H.; Scartazza, A.; Guglielminetti, L. The efficient physiological strategy of a tomato landrace in response to short-term salinity stress. Plant Physiol. Biochem. 2016, 109, 262-272. [CrossRef] [PubMed]

32. Polic, D.; Lukovic, J.; Zorić, L.; Boza, P.; Merkulov, L.; Knezević, A. Morpho-anatomical differentiation of Suaeda maritima (L.) Dumort. (Chenopodiaceae) populations from inland and maritime saline area. Cent. Eur. J. Biol. 2009, 4, 117-129.

33. Liang, W.; Ma, X.; Wan, P.; Liu, L. Plant salt-tolerance mechanism: A review. Biochem. Biophys. Res. Commun. 2018, 495, $286-291$. [CrossRef]

34. Polash, M.A.S.; Sakil, A.; Hossain, A. Plants responses and their physiological and biochemical defense mechanisms against salinity: A review. Trop. Plant Res. 2019, 6, 250-274. [CrossRef]

35. Llanes, A.; Masciarelli, O.; Luna, V. Growth responses to sulfate and chloride are related to different phytohormone profiles in the halophyte Prosopis strombulifera. Emir. J. Food Agric. 2014, 26, 1097-1113. [CrossRef]

36. Chaves, M.M.; Flexas, J.; Pinheiro, C. Photosynthesis under drought and salt stress: Regulation mechanisms from whole plant to cell. Ann. Bot. 2009, 103, 551-560. [CrossRef] [PubMed]

37. Maricle, B.R.; Lee, R.W.; Hellquist, C.E.; Kiirats, O.; Edwards, G.E. Effects of salinity on chlorophyll fluorescence and $\mathrm{CO}_{2}$ fixation in C4 estuarine grasses. Photosynthetica 2007, 45, 433-440. [CrossRef]

38. Moinuddin, M.; Gulzar, S.; Hameed, A.; Gul, B.; Khan, M.A.; Edwards, G.E. Differences in photosynthetic syndromes of four halophytic marsh grasses in Pakistan. Photosynth. Res. 2017, 131, 51-64. [CrossRef]

39. Flowers, T.J.; Colmer, T.D. Salinity tolerance in halophytes. New Phytol. 2008, 179, 945-963. [CrossRef] [PubMed]

40. Shabala, S.; Mackay, A. Ion transport in halophytes. Adv. Bot. Res. 2011, 57, 151-199.

41. Głoniak, P.; Łoś, R.; Skalicka-Woźniak, K.; Widelski, J.; Burczyk, J.; Malm, A. Activity of Crithmum maritimum L. (Apiaceae) against Gram-positive bacteria. Ann. Univ. Mariae Curie-Sklodowska Lub. Pol. 2006, 19, 123-127.

42. Ruberto, G.; Baratta, M.T.; Deans, S.G.; Dorman, H.D. Antioxidant and antimicrobial activity of Foeniculum vulgare and Crithmum maritimum essential oils. Planta Med. 2000, 66, 687-693. [CrossRef]

43. Abbad, A.; El Hadrami, A.; Benchaabane, A. Germination responses of the Mediterranean saltbush (Atriplex halimus L.) to NaCl treatment. J. Agric. 2004, 3, 111-114.

44. Soualem, S.; Kouadria, R.; Labdelli, A.; Adda, A. Effect of GA3, ABA and kinetin on the response of the halophyte Atriplex halimus to salinity during germination. Plant Arch. 2018, 18, 609-615.

45. Hassine, A.B.; Ghanem, M.E.; Bouzid, S.; Lutts, S. An inland and a coastal population of the Mediterranean xero-halophyte species Atriplex halimus L. differ in their ability to accumulate proline and glycinebetaine in response to salinity and water stress. J. Exp. Bot. 2008, 59, 1315-1326. [CrossRef]

46. Belkheiri, O.; Mulas, M. The effects of salt stress on growth, water relations and ion accumulation in two halophyte Atriplex species. Environ. Exp. Bot. 2013, 86, 17-28. [CrossRef]

47. Scholander, P.F.; Hammel, H.T.; Bradstreet, E.D.; Hemingsen, E.A. Sap pressure in vascular plants. Science 1965, 148, 339-346. [CrossRef] [PubMed] 
48. Turner, N.C. Measurements of plant water status by the pressure chamber technique. Irrig. Sci. 1988, 9, 289-308. [CrossRef]

49. Gucci, R.; Xiloyannis, C.; Flore, J.A. Gas exchange parameters, water relations and carbohydrate partitioning in leaves of field-grown Prunus domestica following fruit removal. Physiol. Plant. 1991, 83, 497-505. [CrossRef]

50. Mashilo, J.; Odindo, A.O.; Shimelis, H.A.; Musenge, P.; Tesfay, S.Z.; Magwaza, L.S. Photosynthetic response of bottle gourd [Lagenaria siceraria (Molina) Standl.] to drought stress: Relationship between cucurbitacins accumulation and drought tolerance. Sci. Hortic. 2018, 231, 133-143. [CrossRef]

51. Rivier, L.; Crozier, A. Principles and Practice of Plant Hormone Analysis; Academic Press: London, UK, $1987 ;$ pp. 1-401.

52. Inskeep, W.P.; Bloom, P.R. Extinction coefficients of chlorophyll a and b in N,N-dimethylformamide and $80 \%$ acetone. Plant Physiol. 1985, 77, 483-485. [CrossRef]

53. Jalali, G.A.; Akbarian, H.; Rhoades, C.; Yousefzadeh, H. The effect of the halophytic shrub Lycium ruthenium (Mutt) on selected soil properties of a desert ecosystem in central Iran. Pol. J. Ecol. 2012, 60, 845-850.

54. Lefèvre, I.; Marchal, G.; Meerts, P.; Corréal, E.; Lutts, S. Chloride salinity reduces cadmium accumulation by the Mediterranean halophyte species Atriplex halimus L. Environ. Exp. Bot. 2009, 65, 142-152. [CrossRef]

55. Xu, P.; Drewes, J.E. Viability of nanofiltration and ultra-low pressure reverse osmosis membranes for multi-beneficial use of methane produced water. Sep. Purif. Technol. 2006, 52, 67-76. [CrossRef]

56. Sucre, B.; Suárez, N. Effect of salinity and PEG-induced water stress on water status, gas exchange, solute accumulation, and leaf growth in Ipomoea pes-caprae. Environ. Exp. Bot. 2011, 70, 192-203. [CrossRef]

57. Negrão, S.; Schmöckel, S.M.; Tester, M. Evaluating physiological responses of plants to salinity stress. Ann. Bot. 2017, 119, 1-11. [CrossRef]

58. Slama, I.; Abdelly, C.; Bouchereau, A.; Flowers, T.; Savoure, A. Diversity, distribution and roles of osmoprotective compounds accumulated in halophytes under abiotic stress. Ann. Bot. 2015, 115, 433-447. [CrossRef]

59. Labidi, N.; Ammari, M.; Snoussi, S.; Messelini, N.; Gharbi, F.; Abdelly, C. Stimulated growth rate by restriction of P availability at moderate salinity but insensitive to $\mathrm{P}$ availability at high salinity in Crithmum maritimum. Acta Biol. Hung. 2011, 62, 302-315. [CrossRef]

60. Benzarti, M.; Rejeb, K.B.; Debez, A.; Messedi, D.; Abdelly, C. Photosynthetic activity and leaf antioxidative responses of Atriplex portulacoides subjected to extreme salinity. Acta Physiol. Plant. 2012, 34, 1679-1688. [CrossRef]

61. Sikder, S.; Foulkes, J.; West, H.; De Silva, J.; Gaju, O.; Greenland, A.; Howell, P. Evaluation of photosynthetic potential of wheat genotypes under drought condition. Photosynthetica 2015, 53, 47-54. [CrossRef]

62. Gilliham, M.; Dayod, M.; Hocking, B.J.; Xu, B.; Conn, S.J.; Kaiser, B.N.; Tyerman, S.D. Calcium delivery and storage in plant leaves: Exploring the link with water flow. J. Exp. Bot. 2011, 62, 2233-2250.

63. Fipps, G. Irrigation Water Quality Standards and Salinity Management Strategies; Texas Agricultural Extension Service; A\&M University System: College Station, TX, USA, 2003; pp. 1-19.

64. Bauder, T.A.; Waskom, R.M.; Sutherland, P.L.; Davis, J.G. Irrigation Water Quality Criteria. Ph.D. Thesis, Colorado State University, Fort Collins, CO, USA, 2011.

65. Malakar, A.; Snow, D.D.; Ray, C. Irrigation water quality-A contemporary perspective. Water 2019, 11, 1482. [CrossRef]

66. Tuteja, N. Mechanisms of high salinity tolerance in plants. Methods Enzymol. 2007, 428, 419-438. [PubMed]

67. Cao, W.H.; Liu, J.; He, X.J.; Mu, R.L.; Zhou, H.L.; Chen, S.Y.; Zhang, J.S. Modulation of ethylene responses affects plant salt-stress responses. Plant Physiol. 2007, 143, 707-719. [CrossRef]

68. Wang, B.; Zhang, J.; Xia, X.; Zhang, W.H. Ameliorative effect of brassinosteroid and ethylene on germination of cucumber seeds in the presence of sodium chloride. Plant Growth Regul. 2011, 65, 407-413. [CrossRef]

69. Khan, M.I.R.; Iqbal, N.; Masood, A.; Khan, N.A. Variation in salt tolerance of wheat cultivars: Role of glycinebetaine and ethylene. Pedosphere 2012, 22, 746-754. [CrossRef]

70. Albacete, A.; Martinez-Andujar, C.; Ghanem, M.E.; Acosta, M.; Sanchez-Bravo, J.; Asins, M. J. Rootstock-mediated changes in xylem ionic and hormonal status are correlated with delayed leaf senescence, and increased leaf area and crop productivity in salinized tomato. Plant Cell Environ. 2009, 32, 928-938. [CrossRef] [PubMed]

71. Ghanem, M.E.; Albacete, A.; Martinez-Andujar, C.; Acosta, M.; Romero-Aranda, R.; Dodd, I.C. Hormonal changes during salinity-induced leaf senescence in tomato (Solanum lycopersicum L.). J. Exp. Bot. 2008, 59, 3039-3050. [CrossRef]

72. Shakirova, F.M.; Avalbaev, A.M.; Bezrukova, M.V.; Kudoyarova, G.R. Role of endogenous hormonal system in the realization of the antistress action of plant growth regulators on plants. Plant Stress 2010, 4, 32-38.

73. Tombesi, S.; Nardini, A.; Frioni, T.; Soccolini, M.; Zadra, C.; Farinelli, D.; Palliotti, A. Stomatal closure is induced by hydraulic signals and maintained by ABA in drought-stressed grapevine. Sci. Rep. 2015, 5, 12449. [CrossRef] [PubMed]

74. Yu, Z.; Duan, X.; Luo, L.; Dai, S.; Ding, Z.; Xia, G. How Plant Hormones Mediate Salt Stress Responses. Trends Plant Sci. 2020, 25, 1117-1130. [CrossRef] [PubMed]

75. Gnonlonfin, G.B.; Sanni, A.; Brimer, L. Review scopoletin-A coumarin phytoalexin with medicinal properties. Crit. Rev. Plant Sci. 2012, 31, 47-56. [CrossRef]

76. Tanaka, Y.; Data, E.S.; Hirose, S.; Taniguchi, T.; Uritani, I. Biochemical changes in secondary metabolites in wounded and deteriorated cassava roots. Agric. Biol. Chem. 1983, 47, 693-700.

77. Hamdani, F.; Derridj, A.; Roger, H.J. Diverse salinity responses in Crithmum maritimum tissues at different salinities over time. J. Soil Sci. Plant Nutr. 2017, 17, 716-734. [CrossRef] 
78. Jiménez-Becker, S.; Ramírez, M.; Plaza, B.M. The influence of salinity on the vegetative growth, osmolytes and chloride concentration of four halophytic species. J. Plant Nutr. 2019, 42, 1838-1849. [CrossRef]

79. Hamed, K.B.; Debez, A.; Chibani, F.; Abdelly, C. Salt response of Crithmum maritimum, an oleagineous halophyte. Trop. Ecol. 2004, 45, 151-159.

80. Nedjimi, B.; Daoud, Y. Effect of $\mathrm{Na}_{2} \mathrm{SO}_{4}$ on the growth, water relations, proline, total soluble sugars and ion content of Atriplex halimus subsp. schweinfurthii through in vitro culture. An. Biol. 2006, 28, 35-43.

81. Boughalleb, F.; Denden, M. Physiological and biochemical changes of two halophytes, Nitraria retusa (Forssk.) and Atriplex halimus (L.) under increasing salinity. Agric. J. 2011, 6, 327-339. [CrossRef] 